\title{
Semanas de Sociologia e de Filosofia com Alunos do Ensino Médio da Rede Pública: da Reflexão à Prática ${ }^{1}$
}

\author{
Ângela Maria de Sousa Lima \\ Jaqueline Ferreira ${ }^{3}$ \\ Maria Tereza Orticelli ${ }^{4}$
}

\begin{abstract}
RESUMO
0 trabalho pretende analisar as experiências das Semanas de Sociologia e de Filosofia, realizadas ao longo dos últimos seis anos, com alunos do Ensino Médio, das escolas da rede pública do NRE-Londrina, organizadas por professores, voluntários, alunos e exalunos que participam do GAES (Grupo de Apoio ao Ensino de Sociologia), um Projeto de Extensão do Departamento de Ciências Sociais da UEL. E ao se propor a isso, ou seja, discutir o histórico, o processo de constituição e de relevância educacional desses eventos, o trabalho permite uma reflexão sociológica a respeito da importância da obrigatoriedade e permanência qualitativa da Sociologia e da Filosofia no Ensino Médio no Brasil. Assim como propicia debater a necessidade de redefinição de nossos olhares e intervenções pedagógicas, no trabalho com jovens e adolescentes, através das referidas disciplinas. Entendemos que essas experiências também podem ser pensadas como uma alternativa de trabalho complementar para a diversificação didática no ensino de Sociologia e de Filosofia no cotidiano escolar.

Palavras-chave: Ensino Médio. Escola da rede pública. Ensino de Sociologia e de Filosofia. GAES.
\end{abstract}

\footnotetext{
Abstract

This work has as an objective to analyze the weeks of sociology and of philosophy, which happened in the last six years, with height school students from public schools of the

${ }^{1}$ Parte desse artigo foi apresentada no GT: Ensino de Sociologia, na SBS (Sociedade Brasileira de Sociologia), em Recife, de 29 de maio a 01 de junho de 2007 por Jaqueline Ferreira e Ângela Maria de Sousa Lima.

${ }^{2}$ Professora de Metodologia do Ensino de Sociologia, na Universidade Estadual de Londrina (UEL) e de Sociologia no ICES (Instituto Catuaí de Ensino Superior de Cambe). E-mail: angellamaria@uel.br.

${ }^{3}$ Professora de Sociologia do Instituto Catuaí de Ensino Superior de Cambe (ICES); professora da Rede Estadual de Ensino de Londrina e Representante da Sociologia no NRE/Londrina. E-mail: jaqueferreira@sercomtel.com.br

${ }^{4}$ Professora de Filosofia da Rede Estadual de Ensino de Londrina e representante da Filosofia no NRE/Londrina. Email: orticelli@pop.com.br.
} 
NRE-Londrina, organized by teachers, voluntaries, students and ex-students that have participated of the GAES (Supporting Group to the Sociology Lecturing), an project of extension from the Social Sciences' department from UEL. And by proposing this, that is to say, discuss the historical, the constitution's process and the educational relevance of these events, the work allows a sociological reflection concerning the importance of the mandatory and qualitative permanence of the Sociology and of philosophy in the Secondary School in Brazil. As it prunes to debate the necessity of changing of our views and pedagogical interventions, when working with young people and teenagers, through the referred subject. We understand that this experiences can also be thoughts as an alternative of complementary work to diversify the pedagogical method in the lecturing of Sociology and of philosophy in schools' everyday.

Key words: Height school. Public schools. Sociology and Philosophy Lecturing. GAES.

\section{INTRODUÇÃO}

C onscientes da relevância da obrigatoriedade/permanência definitiva da Sociologia e da Filosofia no currículo do Ensino Médio, das contribuições que as duas ciências podem trazer para a formação dos alunos e dos desafios que ainda são colocados aos professores dessas áreas, nos propomos, nesse artigo, a iniciar um diálogo sobre os primeiros resultados das experiências propiciadas pelas "Semanas de Sociologiae Filosofia" que ocorreram de 2001 a 2007 no Colégio Estadual Nilo Peçanha de Londrina.

Antes de tudo, devemos lembrar que as Semanas são parte integrante de um trabalho histórico realizado por um grupo de professores e alunos do Departamento de Ciências Sociais da UEL, no Laboratório de Ensino de Sociologia (LES) e no Grupo de Apoio ao Ensino de Sociologia (GAES). Por isso, a parte inicial do texto é dedicada a problematizar os desafios da disciplina de Sociologia no Ensino Médio.

Como em muitos momentos da história o processo de institucionalização da disciplina de Sociologia se confunde com a história do processo de institucionalização da disciplina de Filosofia no Ensino Médio e como as Semanas - a partir da segunda edição - reuniu os profissionais das duas disciplinas, não há como refletir sobre esses eventos sem pensar nas intervenções pedagógicas propiciadas por ambas.

Em suma, pretendemos discutir a relevância da disciplina de Sociologia no currículo do Ensino Médio, os desafios colocados aos professores das duas disciplinas, a relação das Semanas com os trabalhos do Laboratório de Ensino de Sociologia (LES) e do Grupo de Apoio ao Ensino da Sociologia (GAES), alguns resultados das Semanas realizadas no Colégio Estadual Nilo Peçanha - enfocando nesse primeiro momento os temas trabalhados a cada edição - para a partir dessas experiências efetuar nossas primeiras reflexões. Mesmo optando por relatos, descrições e entrevistas como recursos metodológicos, ousamos fazer um exercício que perpassa da reflexão à prática e da prática à reflexão. 


\section{A Relevância da Disciplina de Sociologia no Currículo do Ensino Médio: Breves Reflexões}

Iniciamos o artigo reiterando o que já foi dito por Florestan Fernandes (1977) há algum tempo, ou seja, discutir o ensino de Sociologia no nível médio é responsabilidade do sociólogo. Mesmo sabendo que em algumas universidades brasileiras a reflexão ainda se centre mais nos cursos de educação, vale a pena reforçar que qualquer debate sobre as funções da Sociologia no Ensino Médio deve iniciar pela discussão das funções do sociólogo nessa etapa do ensino e a relevância da sua formação no preparo docente para assumir definitivamente esse espaço na escola de educação básica.

Como afirma Amaury C. Moraes (2003), o ensino de Sociologia deve ter um espaço de reflexão da comunidade dos cientistas sociais, pois a formação do professor de Sociologia de nível médio é tarefa também dos professores dos cursos superiores de Ciências Sociais. Nós retiraríamos o termo "também" para dizer que é tarefa primordial dos cursos superiores de Ciências Sociais.

As funções dos cursos de graduação em Ciências Sociais na formação dos futuros professores de Sociologia para o Ensino Médio são cada dia mais desafiadoras. Não basta prepará-los didaticamente. As mediações pedagógicas devem ser pensadas em consonância com a detenção de teorias, pelos futuros professores, que os façam compreender e problematizar melhor temas cada vez mais correlatos: juventude, adolescência, violência, cultura, trabalho, entre outros.

Em outras palavras, não podemos pensar na formação do professor de Sociologia para o nível médio, sem reconhecer que devemos dotá-lo de instrumentos, técnicas e conhecimentos que o permita intervir na realidade escolar sem perder de vista a concepção do que é ser jovem e ser adolescente hoje.

No mesmo grau de importância teórica e prática, ressaltamos que no rol das disciplinas essenciais que compõe a formação desse profissional da educação, devem constar conhecimentos sobre a própria história do processo de institucionalização da Sociologia no Ensino Médio brasileiro. Além de todas as contribuições que essa formação mais completa pode trazer, vale assinalar o fato destes se verem realmente como sujeitos de um momento histórico que ainda reúne boa parte dos esforços daqueles que acreditam no seu potencial formador.

Para ilustrar o debate, mesmo que no momento não possamos aprofundá-lo, ressaltamos o trabalho que vem sendo realizado pelos professores da Universidade Estadual de Londrina (UEL), com base na nova grade curricular e nas experiências propiciadas pelo antigo Laboratório de Ensino de Sociologia (hoje GAES) na redefinição e melhoria da formação dos futuros professores de Sociologia para o Ensino Médio. As Semanas de Sociologia e de Filosofia, tema do qual nos ocuparemos abaixo, é, antes de tudo, produto dessas experiências. 
Tentando ir além das experiências da UEL, lembramos que, ao mesmo tempo que a universidade precisa estreitar seus laços com a escola de educação básica, proposta já mencionada por Florestan Fernandes (1977), ela deve também refletir, juntamente com os órgãos e movimentos de representação desses profissionais, os desafios da formação inicial e continuada do professor de Sociologia.

Segundo Moraes (2003), a própria universidade não reconhece a necessidade de uma formação específica para aqueles que fazem parte de seus quadros, como se fosse suficiente ser pesquisador para ser professor. 0 autor indica que há ainda uma formação deficiente para o exercício do magistério em nível médio, e mais, a excelência característica do bacharelado não é suficiente para superar as falhas da licenciatura.

Moraes alerta que a reforma da licenciatura deve integrar três áreas do conhecimento (teóricos e práticos), necessários para a formação do professor da Educação Básica: específicos, pedagógicos, metodológicos e epistemológicos sobre o ensino. Concordamos com ele quando afirma também que como tem ocorrido com outras disciplinas, "conteúdos programáticos e materiais didáticos" só podem consolidar-se de modo legítimo e eficiente com o concurso de duas iniciativas urgentes: reconhecimento pela comunidade de cientistas sociais de uma área de pesquisa em Ensino de Sociologia; superação do modelo atual de formação do professor de Sociologia, com integração efetiva entre bacharelado e licenciatura (MORAES, 2003)

Não podemos dizer que a realidade educacional seja a mesma dez anos depois, especialmente se pensarmos em todo o processo de árduas lutas dos sindicatos e movimentos sociais que desembocou na Resolução de 16 de agosto de 2007. No entanto, muitos desafios para os profissionais dessa área perduram, dentre eles a mencionada por Moraes no referido artigo, isto é, a dificuldade de consolidação de programas e materiais didáticos, bem como de sua renovação e ou aperfeiçoamento.

Por que continuar a luta pela melhoria do trabalho docente do sociólogo na educação de adolescentes e jovens, luta esta que não é de responsabilidade apenas da universidade e dos movimentos sociais? Porque, em nós, amplia-se a cada dia a crença de queéessencial que a Sociologia consolide seu espaço na formação dos alunos do Ensino Médio.

Em relação às funções dessa disciplina no Ensino Médio, muitas obras poderiam ser mencionadas. Destacaremos apenas algumas. E torna-nos obrigatório iniciar pelas de Florestan Fernandes (1977). Este afirmava que a introdução da Sociologia na escola secundária (hoje Ensino Médio) proporcionaria a formação de personalidades mais aptas à participação política.

Segundo Celso S. Machado (1987,p. 115-116); 
0 ensino de Sociologia permite aos educandos a compreensão da sociedade brasileira de hoje, não como realidades soltas, justapostas ou estéries, mas como totalidade, em seu funcionamento e contradições, complexa, mas não incompreensível, com uma história passada, mas também com sua lógica atual de funcionamento. Permitelhes apreensão efetiva, ainda que em nível médio, de um corpo conceitual mínimo de análise dessa sociedade, não de modo descritivo, fotográfico ou factual, mas de modo mais crítico, científico, penetrante. Permite-lhes terem não só consciência vida da profundidade e gravidade dos problemas e injustiças presentes na sociedade brasileira de hoje, mas também, e principalmente, a compreensão das principais teorias políticas que propõem alternativas de para onde transformar essa sociedade, de quem (ator social) deverá transformá-la e de como transformá-la.

Para Flávio Sarandy (2003), mais que desvelar os chamados "problemas sociais" ou ensinar um elenco sem fim de conceitos, a Sociologia no Ensino Médio proporciona o desenvolvimento da apercepção sociológica.

Nesse contexto, uma das preocupações maiores da Sociologia, como jádisse Sarandy (2003, p. 2);

está em educar o olhar e processar tanto informações como saberes já produzidos [...] 0 conhecimento sociológico certamente beneficia o educando na medida em que lhe permite uma análise mais acurada da realidade que o cerca [...] Mais que isto, a Sociologia constitui contribuição decisiva para a formação da pessoa humana, já que nega o individualismo e demonstra claramente nossa dependência em relação ao todo, isto é, à sociedade na qual estamos inseridos.

\section{Para Leite;}

se é imprescindivel dominar a informática e todas as novas tecnologias para uma colocação qualificada no mercado de trabalho, também se faz necessário, no universo educacional, problematizar a vida do próprio aluno, sua existência real num mundo real, com suas implicações nos diversos campos da vida: ético-moral, sociopolítico, religioso, cultural e econômico [...] e a volta das disciplinas humanísticas - Filosofia, Sociologia, Antropologia, Psicologia, entre outras - tem muito a contribuir com a formação do jovem naquilo que lhe é mais peculiar: o questionamento. Desmistificando ideologias e apurando o pensamento crítico das novas gerações, poderemos continuar sonhando, e construindo, um país, não de iguais, mas justo para mulheres e homens que apenas querem viver. (apud SARANDY, 2003, p. 1);

Muitas considerações poderiam ser feitas para caracterizar as contribuições que a introdução e permanência definitiva das duas disciplinas podem trazer na formação do 
aluno do Ensino Médio e porque não ousar dizer: do Ensino Fundamental. Mas esses pequenos recortes já nos auxiliam a mostrar - o que se traduz em um dos objetivos cruciais desse artigo - que as experiências das Semanas de Sociologia e de Filosofia, realizadas nas escolas da rede estadual de Londrina, podem ser traduzidas como mais uma garantia de espaço que as duas ciências conseguiram entre os alunos e professores do Ensino Médio, bem antes mesmo da resolução de ago/2006. E este trabalho, que só se tornou possível pelas experiências anteriores efetuadas pelos professores do Laboratório de Ensino de Sociologia da UEL, com certeza também tem colaborado no processo de consolidação das duas disciplinas nessa etapa do ensino.

No que diz respeito à garantia da inclusão da Sociologia e da Filosofia no currículo do Ensino Médio brasileiro, muitas batalhas já foram ganhas, porém a vitória ainda não pode ser deliciada por completo. Basta-nos lembrar o exemplo do veto do governador de São Paulo ao projeto aprovado na Assembléia Legislativa e os pareceres do Conselho Nacional de Educação (CNE) contra a obrigatoriedade das disciplinas (BRASIL, 2006). Isso nos permite afirmar que "o processo de institucionalização da Sociologia, por exemplo, dependeu e depende das condições sociais, econômicas e culturais das sociedades modernas." (ANEXO II, 2004, p. 233).

\section{Outros Desafios Estão Colocados}

Asociedade contemporânea se torna cada vez mais complexa, resultado do próprio processo de avanço tecnológico, que se reflete em todas as áreas. Uma tendência diante de tanta complexidade é a atomização de cada ser. Por isso, se torna urgente que a educação consiga superar o fosso que existe entre a realidade do educando, no seu ambiente escolar e no seu convívio social, despertando nele a percepção de que essas duas realidades se interpenetram.

0 desafio que se coloca para a educação, seja nas ciências naturais ou nas ciências humanas, épostular o conhecimento como algo global e permanente, não transmitindoo de forma exata e definitiva, mas preparando o educando para elaborar um saber que está em constante transformação. Para tanto, é preciso que se unam às pesquisas intelectuais, as perspectivas conceptuais e os progressos tecnológicos numa integração global "que tenha por finalidade a formação do homem" (FAURE, 1972, p. 11).

Seja qual for a concepção de mundo do educador, adeptos das correntes teóricas mais variadas, algumas das quais até mesmo em oposição entre si, um fato é admitido e reconhecido: a educação acompanha a economia e a evolução das técnicas de produção, garantindo a transmissão de práticas profissionais, tradições e valores. Esta não paira sobre a sociedade, seus problemas particulares não se distinguem dos problemas sociais, 
políticos e religiosos. Nesse sentido, énecessário aliar, dentro da educação, uma concepção humanista, entendida como sendo o homem e sua realização total o fim a ser atingido, com uma concepção tecnológica, com a aplicação do conhecimento organizado em tarefas práticas e concretas que permita não só a compreensão dos processos objetivos, mas também, uma maior eficácia da sua ação global.

Entendemos que a partir do momento que os profissionais da educação, conseguirem transpor, minimamente que seja, a barreira que se coloca com a fragmentação do ensino, conseguindo fazer a ligação entre o conhecimento escolar e o ser social, boa parte das barreiras serão transpostas. Talvez assim, conseguiremos atingir, o mais próximo possível, o ponto nevrálgico que produz a motivação no aluno. Todavia, a ousadia deve ser a busca no aluno pela sede de aprender, pois "incentivar pela ambição e pela procura de emprego não é suficiente para assegurar a democratização do ensino [...] e também não assegura a perseverança da escolaridade" (FAURE, 1972, p. 28).

Como trabalhar as disciplinas específicas conectadas a esse todo? Vivemos dois pólos de uma mesma situação. De um lado, educadores, de diferentes áreas, tentam "passar" conhecimentos aos seus alunos, com o objetivo de torná-los proficientes nas disciplinas ministradas. De outro, educadores, cheios de "boas intenções", que entendem a necessidade de ir além da especificidade da disciplina, mas não conseguem atingir seus objetivos. Estes últimos acabam presos ao senso comum ou se apropriam de conhecimentos científicos sem transpor a barreira do discurso acadêmico. Assim, atingem apenas a imediaticidade do aluno, o que gera resistências, na medida em que suas falas se tornam um discurso abstrato e distante de sua realidade objetiva. Tal situação é potencializada quando este encontra-se na faixa etária de 13 a 18 anos, o que pela característica inerente à sua idade, mostra-se predisposto a se aborrecer com o discurso.

Gramsci defendia a necessidade de inter-relacionar a vida prática com a eloqüência da vida intelectual, unir o homem especialista ao homem político. A escola é o instrumento para isso. Ela deve proporcionar aos educandos instrumentos que thes permitam ter maior inteligibilidade da sociedade em que estão inseridos, permitindo que se tornem sujeitos conscientes de sua própria história. E isso, não se dá de uma forma espontânea. É necessário organizar a cultura, não como "saber enciclopédico", mas como "organização, disciplina do eu interior, tomada de posse da própria personalidade, conquista de uma consciência superior, pela qual se chega a compreender o próprio valor histórico, a função própria na vida, os próprios direitos e deveres". 0 ideário democrático de "liberdade de expressão" e de "pensamento" só pode ser atingido na medida em que proporcionarmos aos alunos a aquisição de raciocínio lógico, e para isso, a compreensão de sua organização cultural é de extrema importância. A cultura propicia "exercício do 
pensamento, aquisição de idéias gerais, hábito de conectar causa e efeito" (GRAMSCI, 2000, p. 376).

Para Gramsci, a igualdade entre os homens não é o ponto de partida do desenvolvimento histórico, mas de chegada. Énecessário superarmos a igualdade enquanto um conceito abstrato, produzindo nos homens a percepção de que são produtores da igualdade e da desigualdade, ou seja, de sua realidade. Portanto, se faz necessário "reformar o conceito de homem como indivíduo" (SOARES, 2000, p. 412), pois "[...] a natureza humana é o conjunto de relações sociais historicamente determinadas. Mas o conjunto das relações sociais é contraditório em todo o momento e está em contínuo desenvolvimento, assim como a natureza do homem não é algo homogêneo para todos os homens e em todos os tempos" (GRAMSCI, 2000, p. 376).

A arte de operar conceitos não é inata, e tampouco nasce do senso comum, é, portanto uma qualificação. Desse modo, ao elaborar programas didáticos, precisamos levar em conta a "técnica do pensamento". 0 desenvolvimento da "técnica do pensamento", para Gramsci, é tão importante quanto ensinar a ler e escrever. Este é entendido enquanto preparo do educando para adquirir autonomia na construção de critérios de criação e escolha. Não são apenas discursos retóricos, como o processo de "linguagem de conversação entre literatos". 0 autor entende o educando como "[...] conjunto das relações sociais de que os indivíduos fazem parte. Já o educador é formado pela combinação de elementos filosóficos (concepções de mundo) que, através da atividade [...] conseguem reagir sobre a sociedade, modificando a maneira de pensar, sentir e agir [...]" (SOARES, 2000, p. 440).

0 aluno precisa compreender que éparte da estrutura social, que sofre influências e influencia ao mesmo tempo. Se conseguirmos mostrar que eles escrevem sua própria história, através de suas tomadas de decisões, talvez consigamos transformar a educação realmente em agente de emancipação humana. E a universidade tem relevante papel nisso. Independente da área de atuação é salutar lembrar que a universidade possui um compromisso social com a sociedade. A comunidade precisa ter acesso ao saber reelaborado pelas instituições de ensino superior, sejam elas públicas ou particulares.

\section{Laboratório de Ensino de Sociologia (Les) e Grupo de Apoio ao Ensino da Sociologia (Gaes): Onde Tudo Começou!}

Se as Semanas de Sociologia e de Filosofia iniciaram-se nas escolas, primeiramente no Colégio Estadual Nilo Peçanha, bem antes da aprovação da Resolução de ago/2006, foi porque outras iniciativas bem mais consolidadas as precederam. Estamos nos referindo 
ao trabalho realizado pelo GAES (Grupo de Apoio ao Ensino de Sociologia), anteriormente intitulado "Laboratório de Ensino de Sociologia - LES", pelos professores e por alunos que o compuseram.

Essas experiências conquistaram algo bem mais difícil para aquele momento histórico e bem mais complexo do que as atividades que nos propusemos a descrever nesse artigo preliminar, ou seja, a inclusão e o acompanhamento do ensino de Sociologia nas Escolas Estaduais de Londrina, que pode ser certamente denominado como o exemplo mais próximo e concreto de luta na defesa da obrigatoriedade da disciplina de Sociologia no currículo do Ensino Médio. Trabalho este que permitiu também, sempre que possível, alavancar a Filosofia como ciência parceira.

0 Departamento de Ciências Sociais da UEL participou deste processo de reimplantação da Sociologia no currículo do Ensino Médio, durante toda a década de 80 e década de 90. Mas, foi, a partir de 1994 que procurou sistematizar sua atuação nas escolas secundárias de Londrina e região, através de dois projetos de extensão [...].

0 Laboratório foi um projeto de extensão universitária, do Departamento de Ciências Sociais da Universidade Estadual de Londrina, coordenado pela Prof. Ms. Lesi Correa, que visou consolidar um trabalho que já vinha sendo desenvolvido nos projetos "A reimplantação da Sociologia no Segundo Grau" (iniciado em 1994 e encerrado e 1997) e "ASociologia no Ensino Médio, conteúdos e Metodologias: assessoramento aos professores e alunos do $4^{\circ}$ Núcleo de Ensino de Londrina", (iniciado em 1998 e encerrado em 1999) (ANEXO II, 2004, p. 233). Dessa forma, a organização de um Laboratório de Ensino constituiu-se na quarta fase do projeto, iniciado em 1994, ou seja, não foi um projeto diferente, mas de continuidade de um trabalho que já vinha sendo realizado.

Na época, ainda como alunas de graduação, presenciamos a garra e a luta diária dos professores de metodologia de ensino, especialmente do Departamento de Ciências Sociais e de outros integrantes do Laboratório, para conscientizar diretores, coordenadores pedagógicos, professores e alunos do Ensino Médio (antes $2^{\circ}$. Grau) da importância de implantarem as disciplinas na grade curricular de suas escolas.

Este acompanhamento caminhou concomitantemente com a formação de professores e a supervisão dos estágios de licenciatura. E fomos influenciadas pelas marcas desse trabalho "formiguinha" dos professores do Departamento de Ciências Sociais da UEL, pois o objetivo de nos tornarmos professoras do Ensino Médio, transformou-se em alvo bem mais próximo diante dos espaços que o trabalho do Laboratório abriu nas escolas do $4{ }^{\circ}$ Núcleo Regional de Ensino de Londrina na época.

Cada objetivo do projeto de extensão podia ser encarado como um desafio perante uma realidade não muito favorável às duas disciplinas no início da década de 90 . Se bem 
que os professores do Laboratório, no decorrer da década de 80, jáenxergaram nas propostas da SEED/PR algumas brechas para iniciar as reflexões sobre a inclusão das disciplinas no Paraná.

A idéia de iniciar um trabalho de sensibilização sobre a importância da Sociologia na formação dos jovens e dos adolescentes junto às escolas localizadas em LondrinaPR e região, surgiu durante os debates para a reformulação do currículo do Ensino Médio (na época denominado de 2. ${ }^{\circ}$ Grau) do Estado do Paraná, a partir de 1983. Neste ano ocorreu o Primeiro Seminário Estadual de Reorganização do Ensino de 2. ${ }^{\circ}$ Grau, em Curitiba-PR, em que elaborou-se um Documento Síntese para ser refletido nos Núcleos Regionais de Educação. Durante todo o ano de 1984, o Núcleo Regional de Educação de Londrina promoveu discussões com os professores do 1. ${ }^{\circ}$, $2{ }^{\circ} \mathrm{e} 3{ }^{\circ}$ Graus (conforme terminologia daquele período) para elaboração de propostas de reorganização do Ensino nos níveis fundamental e médio. No Seminário Regional de Reorganização do $2 .^{\circ}$ Grau, realizado em Cornélio Procópio-PR, em 1984, as inúmeras propostas foram debatidas e reelaboradas, constituindo-se em novo documento de propostas para 0 2. ${ }^{\circ}$ Grau, que defendia a inclusão da Sociologia e da Filosofia (Anexo II, 2004, p. 232).

Mas em 1988, concluiu-se a Proposta de Reestruturação do 2. ${ }^{\circ}$ Grau no Paraná, e a Filosofia e a Sociologia não foram incluídas como disciplinas obrigatórias no currículo, cabendo às escolas decidirem se as implantariam ou não. Desta forma, algumas escolas implantaram a Filosofia, outras a Sociologia, mas no cômputo geral, pouquíssimas instituições ofertavam estas disciplinas. A complexidade ampliava-se porque o processo de idas e vindas da Sociologia e da Filosofia nos currículos do Ensino Médio impedia que se desenvolvesse uma tradição de ensino destas ciências nas escolas. Se um dos trabalhos iniciais era sensibilizar os profissionais da educação, nas escolas da rede estadual, quanto a relevância da inserção dessas ciências, a carência de materiais e de pesquisas nestas áreas, assim como o incipiente desenvolvimento de metodologias adequadas, de textos didáticos e de recursos, comprometia as parcerias que se estabeleciam naquele instante entre o que as escolas necessitavam e o que o Projeto podia fornecer-lhes.

Consta nos textos do Laboratório que a formação do professor de Sociologia, por exemplo, ficou empobrecida, diante da falta de perspectiva de atuação e da pouca atenção e investimento que os cursos de graduação em Ciências Sociais depositavam na licenciatura.

Colocava-se então a necessidade urgente de reunir um conjunto de ações a serem desenvolvidas no âmbito do Laboratório de Ensino de Sociologia. Desse modo, nas diferentes fases iniciais do Projeto de Extensão, podemos visualizar que as especificidades 
dos objetivos ilustram a diversidade das necessidades postas em cada momento do trabalho: Primeira Fase: Sensibilização para a importância da Sociologia no 2. ${ }^{\circ} \mathrm{Grau}$; Segunda Fase: Acompanhamento da elaboração dos Currículos; Terceira Fase: A Inclusão da Sociologia em todas as Escolas de Londrina; Quarta fase: Laboratório de Ensino de Sociologia. 0 detalhamento dos objetivos, da metodologia e de outros itens do projeto de cada fase, assim como onde concentraram-se cada um destes trabalhos podem ser lidos no texto das professoras Ileiizi L. Forelli Silva e de Lesi Correa, "ANEXO II. Projeto de Extensão Universitária. Laboratório de Ensino de Sociologia. Universidade Estadual de Londrina", no livro organizado por Lejeune Mato Grosso de Carvalho, intitulado "Sociologia e Ensino em Debate: experiências e discussão de Sociologia no Ensino Médio", de 2004.

A monografia "Os lugares da Sociologia no Ensino Médio: o caso da cidade de Londrina, PR, 2007", de Eduardo Carvalho Ferreira, defendida em 2007, também se constitui referência importante para problematizar melhor as especificidades que permearam o desenvolvimento dos trabalhos desenvolvidos pelo LES e pelo GAES.

Não detalharemos tantas outras correlações que existirame existem entre os trabalhos primeiramente desenvolvidos pelos LES e pelo GAES e a idéia de organizar as Semanas. Basta-nos reafirmar que estas constituem-se, desde o início, em apenas um dos muitos outros Planos de Atividades Diferenciadas, que estão atéhoje sendo realizados em consonância com os objetivos e as Atividades Gerais de um projeto que é maior: hoje GAES.

A efetivação dessas semanas temáticas nas escolas, corresponde às intenções e metodologias elaboradas desde a primeira fase do projeto "A Reimplantação da Sociologia no $2 .{ }^{\circ}$ Grau", que tinha como uma das metas iniciar um trabalho de sensibilização sobre a importância da Sociologia na formação dos jovens e dos adolescentes junto às escolas localizadas em Londrina-PR e região. E os eventos tornaram-se possíveis porque houve todo um trabalho anterior que abriu as portas das escolas para acolher a proposta. A própria interdisciplinaridade, que marca o projeto das semanas de Sociologia e Filosofia, encontra espaço na proposta do Laboratório, quando este menciona a possibilidade de "dinamizar processos de ensino interdisciplinar, a partir da Sociologia" (CORREA, 1999/ 2001, p. 6).

Outro propósito das Semanas até hoje já era objetivo do Laboratório no início da década de 90, isto é, auxiliar o professor que ministrava a disciplina de Sociologia a superar as dificuldades relacionadas às especificidades dessa ciência e levar para as escolas propostase metodologias adequadas à fase da aprendizagem de jovense adolescentes.

Concordamos que a atuação do Laboratório de Ensino superou boa parte dessas dificuldades e certamente minimizou bastante os efeitos da tardia institucionalização das Sociologia, e também da Filosofia, nas escolas. 


\section{Semanas de Sociologia e de Filosofia no Colegio Nilo Peçanha}

As Semanas de Sociologia surgiram em 2001, no Colégio Estadual Nilo Peçanha, numa parceria entre a escola e o Laboratório de Ensino de Sociologia, do Departamento de Ciências Sociais da UEL. 0 primeiro evento é também fruto do Projeto Vale Saber e de uma proposta pedagógica interdisciplinar, que reuniu os esforços e ideais da direção, coordenação e um grupo de professores e alunos do Ensino Médio desse colégio com 0 trabalho desenvolvido pelos estagiários de Ciências Sociais e pelas professoras de Metodologia de Ensino de Sociologia da UEL, membros do Laboratório de Ensino de Sociologia.

Não foi uma tarefa fácil. Foram necessários muitos encontros com alunos do Ensino Médio e disposição para conquistar a confiança e o apoio dos professores de outras áreas do conhecimento. Mas os resultados puderam ser vislumbrados logo na primeira programação. Além de auxiliar na organização das palestras focadas em temas sociológicos, professores de outras disciplinas se dispuseram a realizar: confecção de livro de poesias e mural informativo; inserção das Artes; oficinas de pintura, desenho e teatro; eventos culturais; e atividades envolvendo os pais ${ }^{5}$. Estas atividades correlatas despertaram o interesse dos alunos e agregaram um número significativo de organizadores em torno do projeto.

Na nossa avaliação, o modo como as atividades foram desenvolvidas no Colégio Nilo Peçanha incentivou a propagação do evento em outros colégios e a continuidade do trabalho nessa mesma escola. Desde o início a direção da escola se comprometeu a envolver todos os alunos e todos os professores na organização e avaliação do evento.

Outras características das Semanas de Sociologia e de Filosofia nessa escola merecem destaque: monitoria realizada pelos próprios alunos; envolvimento de todos na elaboração das propostas para o ano seguinte; ampliação dos contatos com profissionais de diferentes instituições de pesquisa e ensino superior; atividades específicas preparadas para alunos do Ensino Fundamental; intercâmbio com os pais e a comunidade; diversificação e ampliação crescente da comissão organizadora; antecipação do tempo de organização de cada evento; convite aos ex-alunos das áreas afins; escolha dos temas gerais das semanas pelos próprios professores do colégio; entrosamento com os estagiários de Ciências Sociais e Filosofia da UEL, entre outras ações.

\footnotetext{
${ }^{5}$ Se destacaram como organizadores da primeira Semana, entre outros colaboradores: 2 alunos representantes de cada turma do Ensino Médio, membros da direção e coordenação, 3 professores de Sociologia, 1 professora de Filosofia, 1 professora de Biologia, 1 professora de Língua Portuguesa, 1 professora de História, 1 professor de Matemática, 1 professora de Educação Especial.
} 
Talvez por tudo isso e, sobretudo, por tentar sempre a realização de um trabalho coletivo, as Semanas de Sociologia e de Filosofia continuaram ocorrendo nessa escola ao longo dos últimos sete anos.

SEMANAS DE SOCIOLOGIA E DE FILOSOFIA DO COLÉGIO NILO PEÇANHA

\begin{tabular}{|l|l|}
\hline \multicolumn{1}{|c|}{ TíTULOS DOS EVENTOS } & \multicolumn{1}{|c|}{ DATAS } \\
\hline I Semana de Sociologia no Ensino Médio "Qualidade de Vida" & 08 a 10 de agosto de 2001 \\
\hline $\begin{array}{l}\text { II Semana de Sociologia e I Semana de Filosofia "Educação e } \\
\text { Cidadania" }\end{array}$ & 16 a 18 de novembro de 2002 \\
\hline $\begin{array}{l}\text { III Semana de Sociologia e II Semana de Filosofia "Ética e Relações } \\
\text { Sociais" }\end{array}$ & 30 de setembro a 03 de outubro de 2003 \\
\hline $\begin{array}{l}\text { IV Semana de Sociologia e III Semana de Filosofia "Ler, Pensar e Agir: } \\
\text { da reflexão à prática" }\end{array}$ & 23 a 27 de agosto de 2004 \\
\hline $\begin{array}{l}\text { V Semana de Sociologia e IV Semana de Filosofia "Espaço e Tempo } \\
\text { sob uma perspectiva Sociológica, Filosófica e da Física" }\end{array}$ & 05 a 09 de setembro de 2005 \\
\hline $\begin{array}{l}\text { VI Semana De Sociologia E V Semana De Filosofia Do Colégio } \\
\text { Estadual Nilo Peçanha - Londrina "Ser ou não ser: eis a questão: } \\
\text { Colégio Estadual Nilo Peçanha, 60 anos de história" }\end{array}$ & 23 a 26 de maio de 2006 \\
\hline $\begin{array}{l}\text { VII Semana de Sociologia E VI Semana de Filosofia do Colégio } \\
\text { Estadual Nilo Peçanha com Ensino Fundamental e Médio: "Para onde } \\
\text { Caminha a Humanidade?" }\end{array}$ & 04 a 06 de setembro de 2007 \\
\hline
\end{tabular}

Na I Semana de Sociologia, em 2001, mesmo com a participação de professores de outras áreas do conhecimento e de alguns alunos do Ensino Fundamental, o trabalho centrou-se mais no Ensino Médio e nas temáticas diretamente ligadas às Ciências Sociais: educação; participação e democracia; juventude; clientelismo; desigualdades e violência; ética na política; orçamento participativo; posto indígena; sexualidade; religião; sociedade e mídia; movimento estudantil e regime militar no Brasil; gênero; a era da mulher sujeito; os catadores de papel e a crise do trabalho na atualidade. Na ocasião aconteceram também apresentação de peças teatrais de vários grupos culturais da região, de trabalhos dos alunos realizados na comunidade, palestras ministradas pelas diversas secretarias da prefeitura de Londrina, oficinas de desenho, pintura e teatro.

Em 2002, na II Semana, a partir do interesse dos alunos e dos professores de Filosofia, uniram-se as duas áreas. Essa pareceria permaneceu em todos os demais eventos que se sucederam. Desse modo, novos temas foram inseridos e outros se mantiveram: movimentos sociais; questão agrária; prostituição; cesta básica; direitos humanos; ideologia e consciência política; cultura indígena; cidadania; ALCA; educação alimentar e qualidade de vida; importância da Filosofia no processo educacional; Filosofia: um convite à reflexão; desigualdades sociais; cultura; compromisso social; espaço público; Gilberto freire e a miscigenação no Brasil; importância da Sociologia para a educação e 
a importância da educação para a Sociologia; crise econômica brasileira e bolsa de valores; a interpretação das diferenças na perspectiva da cultura; a Filosofia na multiplicidade de suas vozes; o desafio da liberdade; orientação vocacional; sexualidade; questão de gênero. terceira onda; era da informação; a Sociologia e a construção da cidadania; empreendedorismo social; ONGs e o papel do Terceiro Setor; organização social; questão indígena; Filosofia e emancipação; conscientização e cidadania; papel da filosofia na formação do cidadão; ética e cidadania na sociedade tecnológica.

Já nesse segundo evento muitos alunos manifestaram o desejo de optarem por palestras, montando seu próprio cronograma de participação. Não havendo possibilidade, em função da estrutura física e humana que dispúnhamos naquele instante, pedimos que alguns palestrantes repetissem suas falas e atividades em salas diferentes.

Na III Semana de Sociologia e Filosofia, de 2003, foram debatidos: desigualdade social no Brasil; movimentos sociais: MST; má distribuição de renda no Brasil; rede da cidadania; temas filosóficos; estado de bem-estar social; reforma política; partidos políticos; amor em Comte Sponville; espaço público em Hanna Arenth; a importância da Filosofia; aborto; liberdade na antiguidade cristã; as grandes personalidades do século XX; a importância da participação da juventude na sociedade; preconceito, discriminação racial e pobreza no Brasil; cultura e aprendizagem; ideologia e cultura; a influência da mídia na sociedade; violência nas escolas; análise pedagógica e sociológica os conflitos da adolescência; a educação no sistema capitalista; estado e educação no Brasil; analfabetismo funcional; e movimento estudantil. Além das palestras e oficinas realizadas em sala de aula, programou-se oficinas de artes, esporte, dança e teatro que foram ministradas na quadra. Os alunos do Ensino Médio apresentaram peças teatrais e danças com temas sociológicos. Pela primeira vez, os pais e outros membros da comunidade foram convidados a participar de algumas palestras de seu interesse.

Em 2004, na IV Semana, ampliaram-se muito as temáticas discutidas;

a ação social em Max Weber; a Filosofia mm David Hume; a mulher gorda, a fotografia e a questão do preconceito; aborto; as mudanças no mundo do trabalho; comunicação e questão social; comunicação e relação social; estado, poder, política: suas transformações; gênero e sexualidade; ideologia e cultura; advento da Sociologia como ciência; 0 ato de contar histórias; os jovens que marcaram o século XX; reforma política e partidos políticos; responsabilidade social nas empresas; sensibilização ambiental; sexualidade, prevenção de DST e gravidez; sexualidade: mídia e comportamento; sociedade, pluralidade cultural e etnocentrismo; violência contra a mulher; sistema carcerário e as mudanças no mundo do trabalho; cultura indígena kaingáng; universidade em debate; desigualdade econômica e bolsa de 
valores; estado e educação no Brasil; cultura e aprendizagem; a importância da Filosofia na formação do jovem; classes sociais; método e objeto de estudo em Marx, Weber e Durkheim; educação ambiental; pobreza e má distribuição de renda; a invasão cultural norte-americana no Brasil; amizade em Aristóteles; definindo metas e vencendo desafios; gênero e raça; transformações do mundo do trabalho; discriminação social e racial; movimento social; uma análise sociológica sobre 0 aborto; movimentos sociais e MST; ideologia; relação indivíduo-sociedade; diversidade social; a influência da mídia na sociedade; pobreza e má distribuição de renda; ONGs e terceiro setor; a Filosofia no Brasil: resgate histórico; formas filosóficas de pensar; mulher e trabalho; o que é teatro?; corporeidade e cidadania: uma ponte emergente; introdução ao pensamento sociológico; a religião protestante e as questões geo-culturais; a cultura dos índios kaingáng em Londrina; biblioteca; qualidade de vida; charge e cidadania; os jovens que marcaram o século XX; a questão da mulher; discriminação racial e pobreza no Brasil; advento da Sociologia como ciência; o trabalho hoje; responsabilidade social; a educação no sistema capitalista; temas de Filosofia para o vestibular; Mercosul; a educação no capitalismo; desigualdade e violência; a importância da participação política da juventude; inteligência emocional: conhecendo você mesmo; a questão penitenciária no Brasil; ditadura militar; gênero e ideologia; classes sociais; cultura de massa e indústria cultural; a interpretação de conflitos sociais a partir da interpretação da cultura: reflexões éticas da pósmodernidade; cultura popular brasileira; a questão do meio ambiente; violência nas escolas; Filosofia no ensino médio; uma nova leitura do empreendorismo social; a Mímesis em Platão e Aristóteles; sociedade e meio ambiente; medicina e música como artes; a metáfora do amor no "banquete" de Platão; literatura de massa e literatura erudita; desenho industrial: prática e teoria; artes visuais; o que é Sociologia e 0 que ela estuda; 0 auxílio do Procon na promoção da cidadania; e o "Mito da caverna" dentro de uma perspectiva política.

Processo similar ocorreu em 2005, na V Semana de Sociologia e IV Semana de Filosofia. Muitos assuntos foram acrescidos pela ampliação da equipe de apoio. Fica claro, na análise dos temas incluídos, a constituição de uma teia de trabalho onde várias outras áreas se interaram, especialmente a Física;

adolescência e a segurança; a arte em movimento; Bioética como um conceito relativo; a cultura e a crise de valores na pós-modernidade; a epidemia de aids entre as mulheres; a questão carcerária no Brasil; a questão da mídia hoje; a questão do racismo na contemporaneidade; a sociologia em Marx e Engels; a sociologia no vestibular da UEL; a terra e seu lugar no universo; aborto: em favor da vida; aceleração do espaço-tempo na contemporaneidade; analfabetismo funcional em tempos de 
globalização; arte e literatura: numa abordagem social e pedagógica; as belas mensagens através das histórias; as contribuições da filosofia para a formação do pensamento crítico; astronomia; cultura e mídia; cultura de massa e ideologia; cultura e ideologia; cultura e participação política da juventude; cultura popular e cultura erudita; desigualdade social e democracia; desigualdade social: como discuti-la através da arte dinâmicas pedagógicas; repensando temas sociológicos; educação: caminho a desvelar; o ser egoísmo social ou egoísmo individua;1 especulações sobre o futuro do planeta terra; filosofia: sua inserção no vestibular; ideologia e cultura: sob a perspectiva sociológica e histórica; importância da organização política da juventude; lasers; meio ambiente e responsabilidade social; meio ambiente: um debate sobre os esportes radicais no Brasil; movimentos sociais; o Big-bang e a expansão do universo; o conceito de autonomia na ética de Kant; o cotidiano dos militares durante a primeira e a segunda guerras mundiais; 0 espaço e o tempo na física; o modelo de homem em Nietzsche; o poder da ideologia; orientação profissional; política e juventude; reestruturação produtiva, globalização e transformações que afetam diretamente os trabalhadores no Brasil; reflexões filosóficas e sociológicas sobre a diferença; ser e ter na sociedade capitalista; reflexões sobre a consciência negra; respeitando a cultura kaingáng; responsabilidade social nas empresas; satélites, energia nuclear, GPS: os frutos da revolução que não terminou; sensibilidade musical; ser especial é saber respeitar as pessoas especiais; Sociologia e cinema. Sociologia para vestibulares?; tempo e espaço na Antigüidade grega; tempo real, tempo vivido: representações do tempo; ; cultura indígena; viagem pelo espaço e tempo na Astronomia; violência no Brasil; música; arte/ literatura: transmitindo mensagens sociais; teatro; trabalho em equipe organização e da solidariedade através da música.

Nessa semana introduziu-se os mini-cursos com temas que despertaram maior interesse dos alunos. Dessa maneira, foram agrupadas aulas e turmas no salão maior do colégio para atender mais salas sem o professor necessitar repetir sua atividade, pois percebeu-se o cansaço que isso gerava.

Na VI Semana de Sociologia eV Semana de Filosofia, em 2006, os temas voltaramse para a reflexão das profissões e do mundo do trabalho na atualidade;

importância da Filosofia na formação do ser humano; profissões: contribuições da Sociologia; CF/88: direitos fundamentais do cidadão e advocacia pública; ser pedagogo, o que é?; oficina de rádio comunitária; Você está preparado para o novo mundo? mamãe: cheguei antes!!! E agora? 0 cuidado do recém-nascido prematuro e sua família; historiando a historiografia: conceito e modelos; o papel da UEL na comunidade: projetos ambientais; respeito a pessoas especiais e noções de libras; 
perspectivas profissionais sob um enfoque humanístico; o valor da alimentação saudável; o trabalho pastoral na pós-modernidade; 0 arquiteto de hoje - uma abordagem sobre o profissional da arquitetura na atualidade; o ser em face da linguagem, uma abordagem; o filósofo no mundo antigo e contemporâneo: uma tentativa de desmistificação da sua figura; mãos na terra: construindo hortas escolares; somos iguais: discriminação racial; perspectivas de trabalho do profissional formado em história; orientação vocacional diferenciada; tecnologia e informação; ação afirmativa: o projeto UEL/Afroatitude; Nietzsche e a história; aprendendo a ser e a conviver; saúde indígena; o que é ser arquiteto; contribuição da pesquisa sociológica para o estudo do meio ambiente; energia elétrica e você: prevenção de acidentes com eletricidade; profissão: pedagogo; ser ou não ser; controle populacional de cães e gatos e sua contribuição para o bem-estar animal e a saúde pública; noções práticas do campo profissional da música; como a Psicopedagogia pode ajudar você; Agenda 21: meio ambiente; profissão contador; ser ou não ser no cordel; oficina experimentando a deficiência; atividade física e saúde; aprendendo sobre a ética; energia elétrica e você: prevenção de acidentes com eletricidade; a nova família; educação ambiental; trabalho desenvolvido pelo grupo de estudos continuados em educação ambiental - GECEA/UEL; linguagem visual: interpretação e opinião; 0 que envolve a indústria cultural; discussão sobre a profissão de médico; o que é ser profissional do novo milênio no mercado financeiro; o papel da arte no nosso cotidiano;

Nesse ano, na programação da Semana, incluiu-se: apresentações de danças, como a Dança Árabe, a dança do Grupo do ILECE e do Grupo de Dança da Associação de Pais e Amigos dos Excepcionais-APAE; apresentações musicais, como do Grupo de Experimentação Percussiva da UEL-GEP, do Grupo Vocal Masculino Sollu's, do Grupo G.T.E.P.A.Ê. e do Coral Vozes do ILES; divulgação do livro "A Estalagem das Almas"; e apresentações teatrais, como a peça (sobre a Síndrome de Down) realizada por graduandos da UNIFIL e a encenada por crianças da 4a . série dos Anos Iniciais da Escola Municipal Monteiro Lobato de Rolândia. Estas atividades foram recebidas com muito entusiasmo pelos alunos e permitiram um espaço de reflexão sobre o respeito às especificidades humanas. Além das oficinas de esporte, de música, de teatro, de arte e fotografia, de rádio comunitária, de charge, de vídeo documentário, de leitura de obras de arte, outras temáticas foram trazidas;

música, cotidiano e educação; afinal, o que faz um físico?; os desafios da empregabilidade; Matrix e o mito da caverna; a música em Schopenhauer; investigações filosóficas de Wittgenstein; a enfermagem nos CEIs; reflexões sobre a consciência negra; as diferentes atuações do sociólogo na sociedade 
contemporânea; Matthew Lipman: Filosofia e Filosofia da educação na escola; 0 papel da Educação Física: hoje!; o que envolve a indústria cultural; o que é ser bombeiro?; Profissão: historiadora; o que é ser filósofo; 0 assistente social e suas atribuições no mercado de trabalho atual; uma reflexão, a partir do teatro, sobre Síndrome de Down; patrimônio histórico e turismo: uma construção social; forjando o profissional do futuro: currículo escolar e inovações tecnológicas; crianças e adolescentes em situação de risco; batendo um papo sobre charge; profissão: sociólogo; qualidade de vida e motivação; os meios de comunicação; criando a própria história; possibilidades de trabalho para o profissional de enfermagem; papel do advogado na sociedade; apresentação do projeto de extensão da UEL sobre orientações de segurança em laboratórios e atividades práticas de Química, considerando a melhor destinação dos resíduos; a Sociologia como forma de melhoramento da vida humana; o campo do profissional de Psicologia e outras possíveis intervenções; Fisioterapia: uma questão de escolha; o bem e 0 mal nas Ciências Físicas; o que é ser assistente social; leitura de obras de arte e reflexão sobre a sociedade; o papel do sociólogo; teoria do conhecimento de Platão; mercado de trabalho; o papel do jornalista; ser engenheiro, o que é?; Os desafios da Sociologia na sociedade contemporânea; despertando a comunidade para a importância do conhecimento da consciência fiscal e justiça social para um país; a Ciência Política e nosso cotidiano; o trabalho pastoral na pós-modernidade; Bioética; teoria do conhecimento de Platão; diversidade cultural.

Dois elementos devem ser lembrados na organização da VI Semana. Primeiro, a significativa participação de diferentes projetos de extensão da UEL. Segundo, a pareceria com a UNIFIL, que possibilitou a presença de um número significativo de profissionais na escola, trabalhando com uma variedade de temas, no contexto das profissões.

A sétima edição da Semana de Sociologia e de Filosofia para alunos do Ensino Fundamental e Médio do Colégio Nilo Peçanha ocorreu de 04/09/07 à 06/09/07, com 0 tema geral "Para onde Caminha a Humanidade?" e se dedicou a problematizar o fenômeno da violência.

Presenciamos atualmente em meio à sociedade, uma ascendente manifestaçã̃o de atitudes e ações que se vinculam intensamente ao fenômeno da violência. Esta mesma sociedade, individualista e competitiva, e extremamente violenta, serve de cenário para o estabelecimento de uma variedade enorme de conflitos e disputas, que, em diferentes âmbitos, causam a o sofrimento de um número significativo de pessoas. Capitalismo, drogas, prostituição, ameaças ambientais, consumismo, conflito entre gêneros, corrupção, mídia, imperialismo, xenofobia, autoritarismo e totalitarismo 
só são alguns tópicos que podem ser debatidos dentro de tal tema uma vez que este procura, por meio de um diálogo interdisciplinar, constituir uma reflexão sobre as variadas e ainda não totalmente percebidas, formas de violência na sociedade. 0 Colégio Estadual Nilo Peçanha está propondo neste ano de 2007, desenvolver uma reflexão de modo interdisciplinar que, ao se utilizar das contribuições conceituais da sociologia e a filosofia, venha a fornecer os subsídios necessários para a elaboração de uma análise crítica que à priori, aparente conduzir a sociedade a um processo de desumanização e conseqüientemente a sua própria destruição. (Relatos do professor de Sociologia do Colégio Nilo Peçanha, julho de 2007)

Num processo crescente de autonomia, os projetos e todas as reuniões de organização foram dirigidos exclusivamente pelos professores e alunos do próprio colégio. Neste momento o GAES apenas assessorou e apoiou os planejamentos e os objetivos por eles elaborados;

a referida semana tem como meta poder contribuir por meio da reflexão em meio a ela originada, com a construção de um ser humano solidário, justo e que tenha a defesa da vida como sua meta principal. E é a partir do estabelecimento de um diálogo reflexivo com nossos educandos, que damos início a este importante processo representado na formação não de simples indivíduos reprodutores de uma ordem ou situação social pautada em determinadas conjunturas, mas sim de cidadãos comprometidos com o bem-estar e respeito a toda a sociedade e conseqüentemente com o bem-estar e respeito a si mesmos. A nossa juventude vem sofrendo os efeitos de uma sociedade que vive na realidade, uma crise de referenciais. Inserida dentro dessa sociedade, sofre os reflexos da mesma, e convive com todos os problemas que se originam em seu âmago. Portanto, a Semana de Sociologia e Filosofia do Colégio Nilo Peçanha visa dar oportunidade aos seus alunos e participantes de construírem coletivamente um debate no qual todos possam se enxergar enquanto sujeitos históricos e que como tal encontram-se em situação de questionar e de mudar efetivamente, por meio de sua práxis social, o estado em que se encontra a sociedade a que pertencem. (Relatos do professor de Sociologia do Colégio Nilo Peçanha, julho de 2007)

Muitos dos propósitos elencados pelo professor foram concretizados por meio das atividades que compuseram o evento;

Oficina de Teatro do Oprimido; Como conquistar espaço no mercado de trabalho; Como caminha a humanidade, se é que ela caminha; Angústia e Filosofia: um diálogo com Sören Kierkegaard; Você sabe para onde vai?; Ciência para quê?; Cia de Teatro sob medida "Vamos cuidar do nosso planeta"; Descartes e a Construção 
de uma Ciência verdadeira; Arte e mito: afirmação da vida; Movimentos sociais anti-globalização; Apresentação Balezinho de Londrina; Sensibilização através da música; 0 trabalho e seu futuro: uma abordagem hermenêutica; 0 idoso na cultura africana; Apresentação de Dança Flamenca; As múltiplas formas de violência; Matsuri Dance; Os perigos e desafios da pós-modernidade; Juventude e violência; Legalização de Aborto: Kant e Habermas; A interpretação dos autores clássicos da Sociologia em torno das contradições da sociedade capitalista moderna; Heróis e anti-heróis no submundo global; Apresentação Cultural - Grupo Teia; oficinas de Aquecimento Global; Nossa esperança é imortal; Reflexões sobre a natureza através dos seis elementos; Não dá nada não!Mito ou realidade?; A questão da Violência nas sociedades; Para onde caminha a humanidade: uma reflexão sociológica; Educação na sociedade do conhecimento; Poder Simbólico e industria cultural; Para onde caminha o corpo perfeito?; A retórica das emoções em Aristóteles; Venha descobrir o que a Internet tem para lhe oferecer; Direita e esquerda, origem e fim; Ética e meio ambiente; Imagens sonoras; Um beisterol filosófico: diálogo com alunos da $1^{a}$ série sobre a filosofia; Você sabe o que canta?; História no cotidiano: abordagem ecológica com canções e poesias; Apresentação Teatral (0 problema é meu mas também é seu); Vamos cuidar do nosso planeta; Globalização do narcotráfico; Bioética; Armas Químicas; A paz; A Educação Física e a construção do respeito mútuo; Atividade Física X Sedentarismo; Consumismo e meio Ambiente; How is the humanity walking? The social problems of the people; Por uma outra globalização; Política e Cultura no mundo contemporâneo; A liberdade em Espinosa; Industria cultural e cultura em massa; A arte na era da reprodutibilidade técnica; Violência? Cuidado com ela; Motivação: não procrastine sua vida; Devir, História e Memória; A violência como resultado do modo de produção capitalista; As descobertas matemáticas que caminham com a humanidade; Movimentos culturais da juventude; Filosofia e Linguagem: Instrução Integral; Corpo, mente e coração "os cuidados na adolescência"; 0 querer fazer; Rumo ao Espaço; Para que pagamos impostos; A arte reflete a sociedade; Globalização, pobreza e ODMS da ONU; 0 processo de desconstrução do ser humano no modo produção capitalista; Adolescência e tráfico de drogras; Globalização, pobreza e os ODMS da ONU; Clonagem humana e células tronco; Mundo do Trabalho: uma análise de músicas e clips; Reflexões sobre a violência e meios de comunicação; Redução de danos; Entrevista de emprego; Neoliberalismo e resistência; Não dá nada não! Mito ou realidade??; Clonagem humana e células tronco; Desigualdades de gênero e sexualidade; Histórias em quadrinhos e socialização; Apresentação de Dança APAE CAMBÉ; A problematização social na obra de Monteiro Lobato; As desigualdades sociais e a segregação urbana - Favelas; Por que queremos entender tudo e nos intrigamos com o porquê das coisas?; Nós e os outros. 
A variedade de temas e o fato de nem todos estarem ligados diretamente à questão da violência demonstra que ainda não conseguimos fazer com que o foco de debate delimitado pela escola para cada edição do evento seja integralmente trabalhado. Carecemos de recursos humanos e materiais para concretizar esta meta.

Fazemos questão de registrar todos os temas trabalhados nas sete edições das Semanas no Colégio Nilo Peçanha porque eles ajudam a contar um pouco da história de uma das principais instituições parceiras do LES e do GAES ao longo desses anos. Cabem muitas reflexões em torno das temáticas solicitadas pelos alunos e pelos professores da escola e o modo como foram trabalhadas no decorrer dos eventos. Trabalho que não podemos detalhar nesse primeiro artigo.

\section{A Partir das Experiências: Primeiras Reflexões}

Para nos auxiliar na realização dessa primeira reflexão sobre a Semana de Sociologia e de Filosofia no Colégio Nilo Peçanha recebemos o apoio, em fevereiro de 2007, de um representante de pais, de dois membros da direção e de cinco alunos do Ensino Médio, que haviam participado de pelo menos três eventos consecutivos realizados naescola ${ }^{6}$.

Primeiramente perguntamos à direção, o que as Semanas de Sociologia e de Filosofia representaram para a instituição e para os alunos participantes. A professora, vice-diretora da escola na época, nos respondeu:

é um projeto que há seis anos vem crescendo e melhorando a cada edição. A escola passou a ser reconhecida num contexto mais amplo e os alunos orgulhosos em participar e ver a sua escola mais engajada com a comunidade e as instituições de ensino superior. Uma das maiores contribuições que as Semanas trouxeram para a disciplina de Sociologia e de Filosofia ministradas no Colégio foi a valorização, a ampliação do gosto pela disciplina e da carga horária das mesmas pela escola, contemplada na matriz curricular.

Segundo o aluno ZI, "a maior contribuição esteve em proporcionar visões diferentes do mesmo tema, uma vez que vários especialistas no assunto se propuseram a discuti-los sob vários pontos de vista".

Já na concepção da aluna CA,

as Semanas foram muito importantes, tanto para a ampliação do contexto cultural dos alunos, quanto para a sua formação. Não foi apenas uma semana sem aulas,

\footnotetext{
${ }^{6}$ As pessoas foram convidadas pela direção da escola.
} 
mas foi construtiva em vários pontos: no esforço, no entretenimento e na motivação entre professores e alunos.

A mesma aluna descreve outros benefícios trazidos para as disciplinas de Sociologia e de Filosofia por ocasião da ocorrência desses eventos;

as matérias foram muito mais conhecidas pelos alunos, seus pontos principais, seus temas [...] Podemos abordar tudo dentro da Sociologia e da Filosofia e ainda vimos como podemos aplicá-las no nosso dia-a-dia. Coisas que nem imaginávamos podem se destacar dentro da Sociologia e da Filosofia. Entendemos que a Sociologia e a Filosofia não são só estudo de sociólogos e de filósofos, vai muito além disso.

Quando questionamos sobre qual edição do evento havia sido mais significativa para a escola, a referida aluna nos relatou;

cada semana teve seu diferencial, nada foi igual, teve semanas que os alunos gostaram mais das palestras e teve semanas que gostaram mais das dinâmicas, mas nunca um aluno deve dizer que não gostou de nada. Sempre há algo de interessante para os alunos, algo que chama mais a atenção para um ou para outro, pois nunca vão conseguir agradar a todos [...]. A semana de Sociologia e de Filosofia realizada em 2006 foi muito interessante, pois trabalhou em tema importante no meu ponto de vista: as profissões. Cada palestrante falou um pouco das experiências e teorias a respeito de sua profissão. Há casos que devem ser melhorados, mas é só juntar a disposição do aluno com o interesse do professor. [...] A maioria dos alunos se interessa mais por dinâmicas [...] e por palestras que são realmente interessantes, criativas, que chamam a atenção dos mesmos. Sei que os palestrantes querem mostrar o seu melhor, mas um pouco de criatividade de alguns deles não mata ninguém.

De acordo com JA, "as Semanas foram ótimas, pois trouxeram mais conhecimentos e abriram novos horizontes para os alunos". A aluna também narrou suas preferências, as contribuições trazidas pelos eventos e suas propostas para que os mesmos pudessem ser melhorados;

A semana de Sociologia e de Filosofia nos explica mais sobre o que trabalham cada disciplina e nos ajuda a entender melhor a respeito dessas ciências, nos passando conhecimentos culturais também. Ela nos dá conhecimento social e nos abre os horizontes para o futuro. [...] Minha proposta é que tenha mais prática, de forma a envolver mais os alunos. Fazendo isso, eles se interessarão ainda mais. [...] Gostei mais da semana que discutiu as profissões. As palestras me ajudaram a ter certeza do que eu quero e ajudou muita gente também. Eu me identifiquei mais com esse tema. 
[...] A semana colabora muito com a melhoria do nosso meio social, porque, com certeza, quando um aluno for procurar emprego, vai ter uma visão mais ampla e muito mais conhecimento [...] Os alunos gostaram mais das partes práticas, como o coral, as danças, etc. Acho que a parte de atividade em sala é ótima, mas a prática é melhor ainda, transmite-nos mais cultura. A Semana de Sociologia nos ajuda muito a pensar no nosso futuro, ajuda a formar novos cidadãos.

0 aluno TI nos relatou que "a Semana de Sociologia e de Filosofia foi uma forma encontrada pela escola para tentar mostrar aos alunos um pouco mais da importância do estudo dessas disciplinas, de uma maneira diferente daquela que é ensinada em sala de aula". Ele acrescenta;

[...] a maior contribuição desse evento foi mostrar os mesmos assuntos, porém com visões e opiniões diferentes [...] Gostei mais da semana de 2006, das palestras voltadas para as profissões, o que pode ter servido de ajuda aos alunos que ainda não haviam se decidido sobre seu futuro [...] Gostei muito mais da parte prática, das gincanas, competições, apresentações, etc [...] Porém, teve muita palestra também focada num mesmo tema, isso não foi tão interessante para os alunos.

Quando interrogamos sobre a semana mais significativa e os problemas e/ou propostas que poderiam ser elencados a partir dessas experiências, uma das representantes da atual direção da escola nos relatou;

A Semana de Sociologia e de Filosofia mais significativa já realizada na escola, foi a última Semana, pois ampliou-se as experiências adquiridas a partir da organização de eventos anteriores e 0 tema motivou enormemente os alunos. [...] Como problemas elenco o fato da escola ter se tornado pequena diante da amplitude dos eventos e as dificuldades enfrentadas em dotar, simultaneamente, todos os palestrantes com recursos audiovisuais. Como propostas, sugiro solicitarmos o envolvimento do Departamento de Artes da UEL para realizar apresentações culturais durante a Semana.

Pudemos perceber avaliações correlatas dos alunos do Ensino Médio quando essa mesma pergunta lhes foi dirigida. As indicações também não destoaram das colocações gerais feitas pelos demais alunos, no encerramento de cada semana, quando cada monitor eleito pela turma se reuniu com a comissão de organização para fazer o feedback da atividade.

Falar sobre as profissões foi excelente porque é completamente aplicável ao nosso universo jovem, mas foram expostas profissões mais nas áreas de humanas, o que foi uma pena, mas mesmo assim foi bom. [...] Estrategicamente, as atividades 
promovidas pela Semana devem ser mais dinâmicas. A Comissão precisa adiantar os temas a serem abordados para os alunos para que eles possam se organizar anteriormente, pois, nem todos gostam dos mesmos temas. Mesmo assim, se forem trabalhados de modo mais dinâmico, os alunos aceitariam melhor os novos conhecimentos. [...] Eu gostei mais das atividades feitas na quadra: dança, teatro, bandas e o Coral do ILES (Aluna TA, entrevista fev/07)

Sobre os eventos, o aluno ZI comentou;

A discussão de temas sociais e filosóficos contribui, em certos aspectos, pois podendo identificar os males, podemos encontrar formas e soluções desses problemas [...] Mas, talvez com palestras mais dinâmicas os alunos se interessassem mais. Gostei mais das palestras sobre profissões do ano passado, pois os alunos tiveram uma visão de como estas funcionam, ajudando-os assim a escolher a profissão que mais thes favoreceriam. [...] Na ocasião, além de palestras sobre temas ligados a problemas de estudo da Sociologia e da Filosofia, houveram atividades sobre as profissões.

A professora, representante da direção, também enfatizou;

É importante a presença de profissionais das mais diversas áreas no colégio, aproximando os alunos das instituições de ensino superior e da comunidade em que estão inseridos [...] A Universidade é a primeira parceira na realização de eventos no colégio. Esse apoio é fator preponderante para o sucesso alcançado. Recebemos certificados e apoio técnico-organizacional do GAES, do Departamento de Sociologia e de Filosofia [...] Quando os seus integrantes apostam na idéia e usufruem dessa idéia, conclui-se que toda a comunidade local é premiada, com alunos mais críticos, observadores e participativos. Nessa somatória possibilita-se a formação de seres humanos mais sensíveis e engajadores no meio social, além de melhores profissionais no mercado de trabalho.

A relevância do estreitamento dos laços entre a universidade e a escola é ressaltada também na fala de uma mãe de aluno participante das atividades há alguns anos consecutivos. Segundo ela, "a importância do evento está, sobretudo, na importância do relacionamento que os alunos e a escola têm como a universidade. Essa proximidade desperta neles a possibilidade de fazerem parte do mundo universitário, despertando os seus sonhos, levando-os em busca do conhecimento".

A direção lembrou ainda que o projeto tornou-se já parte integrante da Proposta Pedagógica da Escola (PPP): "procurando atender os novos alunos e a comunidade em atividades culturais e educacionais, a Semana de Sociologia e de Filosofia é abordada em atividades escolares e ações didático-pedagógicas a serem 
desenvolvidas ao longo do calendário escolar". E o fato dos organizadores trabalharem, desde a primeira edição do evento, com o apoio dos professores das demais disciplinas, promoveu a necessidade de fazer dele uma proposta interdisciplinar. Nesse intuito, há total abertura, por parte da escola e do GAES, para que os temas trabalhados nos eventos sejam construídos na discussão realizada pela própria escola, visando criar uma teia de intercâmbios, ou seja, é possível buscá-los nos mais diversos campos/áreas e esses temas oportunizarem 0 aprimoramento dos conhecimentos já adquiridos pelos alunos, além de ampliar os espaços de troca de experiências entre professores e alunos dentro da escola, e promover também maior diálogo entre os diferentes profissionais da escola com entidades, movimentos e demais instituições de ensino.

Segundo relatos da aluna TA;

As Semanas de Sociologia e de Filosofia na escola foram propostas de ousadia, para adicionar conhecimento, de forma geral, entre os alunos. Elas representaram maior reconhecimento educacional da escola e para os alunos foi uma maneira construtiva de ampliar suas visões de mundo. [...] As Semanas mostraram os temas que a Sociologia e a Filosofia abordam como um todo, tanto no campo profissional como na visão de mundo dos alunos, demonstrando como elas adicionam à sociedade. As semanas significaram maior amadurecimento para os alunos na questão social [...] Elas colaboraram socialmente, pois a sociedade irá colher para si jovens mais maduros profissionalmente e culturalmente, assim como cidadãos mais praticantes.

Alguns pontos levantados pelos alunos, pela mãe e pela professora representante da direção exigem de nós (organizadores) reavaliações e planejamentos melhor estruturados, caso possamos continuar desenvolvendo esse trabalho com a escola.

As falas da direção destacaram, nessa primeira avaliação, mais pontos positivos do que problemas a serem encaminhados para futuros planejamentos. Tal posicionamento pode ser justificado facilmente na luta que a escola tem engendrado para garantir todos os anos pelos menos uma edição do evento no contexto dos problemas estruturais que, de maneira geral, obstaculizam essa como a viabilização de outras atividades extra-classe. É óbvio que esses pontos podem ser lidos também como propostas de continuidade: maior intercâmbio com profissionais do ensino superior; parceria com a universidade, com os departamentos envolvidos e com o GAES; reconhecimento maior da escola e das disciplinas de Sociologia e de Filosofia; ampliação de horas-aula das duas disciplinas na grade curricular; o fato das Semanas se tornarem um projeto maior, interdisciplinar, próprio da escola, inclusive com o mérito de ser inserido no seu PPP; e crescente valorização da Sociologia e da Filosofia entre alunos e professores das 
demais disciplinas. Relembramos que os relatos da mãe de aluno também destacaram a relevância do trabalho de parceria entre a escola e a universidade.

A professora, que nessa entrevista disse representar o posicionamento da direção da escola, mencionou duas necessidades imediatas que, uma vez sanadas, potencializariam as atividades realizadas durante os eventos: ampliação dos espaços e das verbas para atender à todos os palestrantes e oficineiros com material de apoio.

Muitos outros recursos seriam necessários para atender às expectativas que uma parceria como esta demanda. APROEX (Pro-reitoria de Extensão da UEL), tem auxiliado em todos os projetos relacionados às Semanas de Sociologia e de Filosofia, realizados pelo Laboratório e pelo GAES, desde o início, nesta e em outras escolas da rede pública e privada do NRE/Londrina, porém esse apoio écada vez mais incipiente perante a ampliação crescente, dos convites enecessidades trazidas pelas escolas parceiras. Incentivos definidores, advindos da própria universidade, como os certificados confeccionados pela PROEX, a divulgação em diferentes meios, o fornecimento do transporte e de recursos financeiros para a confecção de alguns materiais, apoio financeiro aos estagiários, dentre outras contribuições, não devem ser colocadas em segundo plano, afinal sem elas, talvez as Semanas não pudessem ser realizadas.

Questionamos, no entanto, a desvalorização que ainda demarca os projetos e pesquisas desenvolvidas pelas licenciaturas em geral e pelos cursos da área de Ciências Humanas no país, por parte dos órgãos responsáveis pelo planejamento e efetivação das políticas públicas de educação.

Nas falas dos alunos fica evidente que a proposta contribuiria melhor com sua formação, se pudéssemos reunir mais estrutura e recursos para pôr em prática os planejamentos dos oficineiros, organizadores, monitores, alunos, professores da escolae palestrantes. Significativa gama de esforços advem mais do trabalho voluntário do que de políticas públicas com fins mais duradouros, processo este que precisa ser revertido.

De quais necessidades levantadas por eles estamos falando? Dentre outras: trabalhos mais dinâmicos e práticos; antecipação na organização das atividades; maior diversificação de temas e de palestrantes; promoção de mais atividades extra-classe; realização de palestras e oficinas mais criativas. Enfim, há de se registrar que a carência de materiais de apoio, que vão do xérox de um artigo ao aluguel de um "data show", tem influenciado o ritmo e a execução dos trabalhos nesses eventos. Não podemos fazer uma relação direta entre criatividade, dinamismo e recursos materiais. Nem a fala dos alunos pode ser sintetizada nesses aspectos. Porém, diante do número de estudantes atendidos, a carência de material de apoio tem sido uma das maiores dificuldades enfrentadas pela equipe. 
Anima-nos enormemente saber que, mesmo com as dificuldades estruturais por nós levantadas, os alunos do Ensino Médio da referida escola perceberam grande aproveitamento nesses eventos. Ressaltamos o fato de observarem a amplitude do campo de análise da Sociologia e da Filosofia como ciências importantes na sua formação e de mencionarem que a discussão de temas sociológicos e filosóficos colabora na ampliação de suas visões de mundo.

Pela proximidade temporal entre a data do último evento e a das entrevistas, também merece destaque a quantidade de vezes que a Semana de Sociologia e de Filosofia que tratou do tema "profissões", surgiu nos relatos dos alunos. Estes demarcaram ter conseguido maior aproveitamento da Semana que se propôs a refletir a problemática do mundo do trabalho e das profissões.

Não aprofundaremos a questão nesse artigo, mas podemos colocar como uma das prováveis hipóteses o interesse dos alunos, nessa faixa etária e nessa etapa do ensino, em definir o futuro em meio às dúvidas que normalmente pairam sobre jovens e adolescentes em relação a escolha da profissão, e hoje em um contexto de instabilidade permanente que marrca o mundo do trabalho para grande parte dos brasileiros, em especial desses alunos.

Lembramos que em um de seus relatos a professora disse, em nome da direção da escola, que as Semanas de Sociologia e de Filosofia se tornaram propostas realmente interdisciplinares.

A luta por políticas públicas de educação duradouras, de apoio às licenciaturas, deve ser travada em consonância com a luta pela valorização do trabalho dos profissionais da educação, que hoje extrapola a reivindicação por maiores salários e melhores condições de trabalho.

Cabe pontuar que o texto carece de relatos de professores da escola, principalmente de Sociologia e de Filosofia que, no momento das visitas, não pudemos coletar. Não constam também relatos sobre a sétima edição da Semana, que no momento das entrevistas estava sendo organizada.

Em relação às Semanas de Sociologia e de Filosofia do Colégio Nilo Peçanha, outras tantas considerações poderiam ser feitas, mas nesse primeiro momento nos atemos a resumi-las nos aspectos até aqui mencionados. Vale dizer que as Semanas organizadas no Colégio acabaram impulsionando a extensão desse trabalho em outras instituições.

Outro resultado do trabalho desenvolvido culminou na realização do "I Encontro Regional de Filosofia e Sociologia com Alunos e Professores do Ensino Médio", intitulado "Temas Contemporâneos em Filosofia e em Ciências Sociais", que ocorreu na UEL, de 02 a 04 de agosto de 2007. 0 evento se propôs a refletire comemorar um ano da obrigatoriedade 
das duas disciplinas no currículo do Ensino Médio e contribuir com o processo de ensino e aprendizado de Sociologia e Filosofia no Ensino Médio. A atividade representou o acúmulo das experiências adquiridas com a elaboração das semanas, permitindo a participação de um número bem maior de alunos e de professores (da rede pública e privada), maior intercâmbio e interação destes com os Cursos de Filosofia e Ciências Sociais, solidificando a parceria escola/universidade.

\section{Considerações Finais}

Para nós, o ideal é que as Semanas de Sociologia nasçam realmente nas escolas, a partir das motivações interdisciplinares entre professores das diversas áreas, do trabalho desenvolvido pelos professores de Sociologia e de Filosofia, do interesse dos alunos pelas duas disciplinas. Desejamos que o GAES possa apenas assessorá-los, valorizando a autonomia das escolas frente à estas ações. Ideal que nãoé mais distante, visto a experiência conduzida pelo Colégio Estadual Nilo Peçanha.

Enquanto professores de Sociologia e Filosofia, temos consciência dos desafios que este trabalho nos coloca. Para nós, tais eventos são muito relevantes na medida em que proporcionam maior reflexão sociológica e filosófica a respeito da importância da permanência qualitativa das duas disciplinas no currículo do Ensino Médio, permitem pensar a relevância da inserção das mesmas no Ensino Fundamental, assim como propiciam debater a necessidade de redefinição de nossos olhares e intervenções pedagógicas, no trabalho com jovens e adolescentes, através das referidas áreas do conhecimento.

Entendemos que essas experiências também podem ser pensadas como uma alternativa de trabalho complementar para a diversificação e enriquecimento teórico-metodológico do ensino de Sociologia e de Filosofia no cotidiano escolar por toda complexidade e diversidade de metodologias, mediações, recursos e projetos que a cada edição são apresentados pela escola e para a escola no desenvolvimento dos eventos.

Assim, uma Semana de Sociologia e de Filosofia constitui-se num esforço coletivo de instrumentalização didática, baseada na pedagogia histórico-crítica, na organização dos conteúdos e de atividades de ensino-aprendizagem que realmente contribuem com 0 enriquecimento dos conteúdos dos alunos, pois supõe-se que estes conhecimentos, problematizados nos eventos, podem influenciar futuras práticas sociais e educacionais.

É claro que não proporcionarão resultados se forem problematizados de modo isolado. Como afirma Ileizi L. Fiorelli Silva (2005b), precisamos pensar na constituição 
de um Projeto de Ensino Médio que envolva os adolescentes e os jovens em experiências significativas do ponto de vista coletivo, sem rejeitar a escola e os conteúdos científicos. Isso implica em defender um currículo que busque uma educação científica e humanista e um trabalho de mediação pedagógica, que leve aos alunos o acúmulo de reflexões ou o estado da arte das disciplinas. E ela vai além, ao afirmar que a Sociologia, como qualquer outra disciplina, só faz sentido se for delimitada dentro de um projeto maior de educação, de formação dos adolescentes, dos jovens e dos adultos. (SILVA, 2005a). Estes propósitos nos conduzem à oitava edição da Semana de Sociologia e de Filosofia no Colégio Estadual Nilo Peçanha.

\section{REFERÊNCIAS}

ANEXO II. Projeto de Extensão Universitária. Laboratório de Ensino de Sociologia. Universidade Estadual de Londrina. In: CARVALHO, Lejeune Mato Grosso de (Org). Sociologia e Ensino em Debate: experiências e discussão de Sociologia no Ensino Médio. Ijí: Ed. Unijuí, 2004. p. 233 a 263.

BRASIL. MEC. OCNS: Orientações Curriculares Nacionais. Sociologia. Brasília, 2006.

CARVALHO, César Augusto de; CORREA Lesi (Coord.). Laboratório de Ensino de Sociologia. Fase II. Projeto de Extensão Universitária. Londrina: Departamento de Ciências Sociais, Universidade Estadual de Londrina, 2003-2005.

CORREA Lesi (Coord.). Laboratório de Ensino de Sociologia. Fase I. Projeto de Extensão Universitária. Londrina: Departamento de Ciências Sociais, Universidade Estadual de Londrina. 1999-2001.

FAURE, Edgard. Aprender a ser. São Paulo: Bertrand, 1972.

FERNANDES, Florestan. 0 ensino da Sociologia da escola secundária brasileira. In: A Sociologia no Brasil. Petrópolis: Vozes, 1977.

GRAMSCI, Antonio. Problemas da vida cultural: a formação dos intelectuais. In: SOARES, R.D. Gramsci, o Estado e a escola. Ijuí: Unijuí, 2000.

MACHADO, Celso de Souza. 0 Ensino da Sociologia na escola secundária brasileira: levantamento preliminar. Revista da Faculdade de Educação, São Paulo, v. 13, n. 1, p. 115-142. jan/jun. 1987.

MORAES; Amaury César. Licenciatura em Ciências Sociais: 0 ensino de Sociologia, entre 0 balanço e o relato. Tempo Social, São Paulo, v.15, n. 1, p.5-20, maio 2003.

PARANÁ. SEED. Diretrizes Curriculares de Sociologia. Curitiba, 2006.

SARANDY, Flávio Marcos Silva. Reflexões acerca do sentido da Sociologia no Ensino Médio: 
desenvolver a perspectiva sociológica: objetivo fundamental da disciplina no Ensino Médio. Revista Espaço Acadêmico, ano 1, n. 5, out. 2001. Disponível em: http:// www.espacoacademico.com.br/005/05sofia.htm. Acesso em 2 fev. 2007.

SILVA, Ileizi Luciana Fiorelli. A Sociologia no Ensino Médio: os Desafios Institucionais e Epistemológicos para a Consolidação da Disciplina. In: CONGRESSO BRASILEIR0 DE SOCIOLOGIA, 12., 2005, Belo Horizonte. Sessão Especial: ensino de sociologia em questão. Belo Horizonte, 2005a.

SILVA, Ileizi Luciana Fiorelli. Ensino dos Fundamentos Sociológicos da Educação: pressupostos e metodologias. In: SIMPÓSIO DA EDUCAÇÃO PROFISSIONAL DO CURSO DE FORMAÇÃO DE DOCENTES, 1., 2005, Faxinal do Céu. Anais... Curitiba: Secretaria de Estado da Educação, 2005b.

SOARES, R.D. Gramsci, o Estado e a escola. Ijuí: Unijuí, 2000. 